\title{
NOTE
}

\section{Contribution of methanotrophs to freshwater macroinvertebrates: evidence from stable isotope ratios}

\author{
S. I. Kiyashko ${ }^{1, *}$, T. Narita ${ }^{2}$, E. Wada ${ }^{2}$ \\ ${ }^{1}$ Institute of Marine Biology FEB RAS, Vladivostok 690041, Russia \\ ${ }^{2}$ Center for Ecological Research Kyoto University, Otsu 520-2113, Japan
}

\begin{abstract}
Carbon and nitrogen isotopic composition of infaunal invertebrates from profundal and littoral zones of Lake Biwa, central Japan, was studied. Samples of chironomid larvae, Stictochironomus sp., showed large variations in both $\delta^{13} \mathrm{C}$ values (-64.0 to $-23.0 \%$ ) and $\delta^{15} \mathrm{~N}$ values (-1.3 to $8.8 \%$ ) and were significantly depleted in both ${ }^{13} \mathrm{C}$ and ${ }^{15} \mathrm{~N}$ in comparison to other animals and primary producers from this lake. Moreover, $\delta^{13} \mathrm{C}$ values lower than $-40 \%$ are unusual for freshwater food webs based on photoautotrophic sources. There was a strong positive correlation between $\delta^{13} \mathrm{C}$ and $\delta^{15} \mathrm{~N}$ values of Stictochironomus sp., which clearly indicates a mixing of nutrition from 2 isotopically distinct sources. We presume that, other than photoautotrophic producers, only methanotrophic bacteria, which utilize isotopically light methane, could provide a source that is so depleted in both ${ }^{13} \mathrm{C}$ and ${ }^{15} \mathrm{~N}$. We suspect that the trophic association of some Chironomidae species with methanotrophic bacteria may turn out to be a widespread phenomenon.
\end{abstract}

KEY WORDS: Chironomidae - Methanotrophic bacteria Feeding $\cdot$ Stable isotopes

Resale or republication not permitted without written consent of the publisher

Bacteria that utilize methane form the base of a food chain, independent of photosynthesis, near oceanic cold gas seeps (Childress et al. 1986, Fischer 1990, Cavanaugh 1993). However, the incorporation of methanotrophic bacterial pathways into food webs in freshwater ecosystems, where anaerobic methanogenesis provides large quantities of biogenic methane, has not been well documented (Hanson \& Hanson 1996).

Thermogenic and especially biogenic methane is depleted in ${ }^{13} \mathrm{C}$ with respect to all photoautotrophic primary producers of organic carbon (Whiticar et al. 1986). Additional fractionation of ${ }^{13} \mathrm{C}$ during microbial

*E-mail: inmarbio@mail.primorye.ru oxidation of methane results in unusually low levels of $\delta^{13} \mathrm{C}$ in methanotroph biomass compared to all other organisms in nature (Whiticar \& Faber 1986). Thus, the incorporation of methanotrophs into the food chains of metazoan organisms should be easily recognized from the carbon stable isotope ratios of consumers.

The incorporation of methane in marine animals bearing symbiotic methane-oxidizing bacteria was confirmed by the very light $\delta^{13} \mathrm{C}$ values ( -74 to $-45 \%$ ) of their tissues. These animals included bivalve mollusks from the Florida Escarpment (Paull et al. 1985, Cary et al. 1989) and the Louisiana hydrocarbon seep sites in the Gulf of Mexico (Kennicutt et al. 1992), and a small pogonophore, Siboglinum poseidoni, dwelling in sediments from the Skagerrak (Schmaljohann et al. 1990). However, methane was not apparently incorporated into non-symbiotic animals inhabiting a North Sea site with an active methane seep, based on $\delta^{13} \mathrm{C}$ measurements (Dando et al. 1991). In freshwater ecosystems, $\delta^{13} \mathrm{C}$ data have shown that zooplankton in some small lakes selectively feed on food sources isotopically lighter than bulk particulate organic matter, suggesting grazing on methanothrophic bacteria (Bunn \& Boon 1993, Jones et al. 1999).

In this work we present results of a carbon and nitrogen isotope survey of benthic animals in Lake Biwa, demonstrating the first evidence that methanotrophs support particular species of freshwater metazoan consumers.

Materials and methods. Lake Biwa is the largest lake in Japan with a maximum depth of $104 \mathrm{~m}$ and a water volume of $27.5 \times 10^{9} \mathrm{~m}^{3}$. In the last decade the lake has shifted from an oligotrophic to a mesotrophic condition due to increasing eutrophication (Okuda \& Kumagai 1995). Thermal stratification is well established in mid-summer and early autumn (Okamoto \& 
Morikawa 1961), resulting in a decrease of dissolved oxygen concentration in the hypolimnion down to $3 \mathrm{mg}$ $\mathrm{l}^{-1}$ (Nishino et al. 1998). Profundal macrozoobenthos is represented in the lake mainly by oligochaetes with rare chironomid larvae (Mori 1978, T. Narita unpubl.).

Samples of macrozoobenthos were collected by a grab sampler from March through June 1999 in the middle part of the lake off Shinkai-hama in the 73 to $5 \mathrm{~m}$ water depth range. More than 20 grab samples of littoral sand were sampled from $5 \mathrm{~m}$ water depth to obtain several samples of diverse chironomid larvae from the single site of a restricted area approximately $200 \mathrm{~m}^{2}$. Animals were collected from the sediment after sieving with a $250 \mu \mathrm{m}$ mesh, kept alive for $48 \mathrm{~h}$ in filtered lake water to clean the gut, and then dried at $60^{\circ} \mathrm{C}$ and ground with an agate pestle and mortar. Generally 3 to 12 individuals of the same species were pooled in each sample.

Carbon and nitrogen stable isotope ratios were analyzed in the $1 \mathrm{mg}$ powdered samples using a $\mathrm{CNH}$ analyzer combined with a Finnigan MAT Delta-S massspectrometer through a Conflo-II interface. Isotope ratios were expressed in $\delta$ notation as follows:

$$
\delta X(\%)=\left[\left(R_{\text {sample }} / R_{\text {standard }}\right)-1\right] \times 10^{3}
$$

where $X$ is ${ }^{13} \mathrm{C}$ or ${ }^{15} \mathrm{~N}$, and $R$ is ${ }^{13} \mathrm{C} /{ }^{12} \mathrm{C}$ or ${ }^{14} \mathrm{~N} /{ }^{15} \mathrm{~N}$. PeeDee Belemnite (PDB) carbonate and atmospheric nitrogen were used as the standards for carbon and nitrogen, respectively. The $\delta^{13} \mathrm{C}$ and $\delta^{15} \mathrm{~N}$ values were reproducible with a precision of $\pm 0.1 \%$.

Results. The stable isotopic ratio survey of profundal macrobenthic invertebrates of Lake Biwa revealed that chironomid larvae of Stictochironomus sp. were unusually depleted in ${ }^{13} \mathrm{C}$ and ${ }^{15} \mathrm{~N}$ in comparison to other aquatic animals (Table 1). Samples of Stictochironomus sp. showed $\delta^{13} \mathrm{C}$ values from -64.0 to $-34.3 \%$, much lighter (more negative) than those of other pro- fundal infauna, which exhibited a range of -28.6 to $-23.9 \%$. Collected larvae of other chironomid species showed an average $\delta^{13} \mathrm{C}$ value of $-27.7 \%$, only slightly lighter (ANOVA, $\mathrm{p}=0.0024)$ than that of oligochaetes $(-26.0 \%)$, the most abundant animals in the profundal infauna.

The $\delta^{15} \mathrm{~N}$ values of Stictochironomus sp. $(-1.3$ to $+7.2 \%$ ) were also much lighter (less positive) than those of other profundal infauna samples narrowly clustered in the +10.1 to $+13.1 \%$ range. However, there was no significant difference in $\delta^{15} \mathrm{~N}$ values between other chironomid species and oligochaete samples (ANOVA, $p=0.79$ ).

More extensive sampling in sandy littoral enabled us to obtain more samples of Stictochironomus sp. and 12 other species of infaunal chironomid larvae for comparative isotopic analysis (Table 1). Composite samples of Stictochironomus sp. obtained from a limited area showed a very broad range of the $\delta^{13} \mathrm{C}$ values from -45.0 to $-23.0 \%$, which were non-normally distributed. Littoral Stictochironomus sp. were significantly ${ }^{13} \mathrm{C}$-depleted in comparison to samples of other species of chironomid larvae from this setting (Kolmogorov-Smirnov test, $\mathrm{p}<0.01$ ). The $\delta^{13} \mathrm{C}$ values for the latter were narrowly clustered around a mean value of $-22.5 \pm 0.9 \%$ o $(n=27)$. Littoral samples of Stictochironomus sp., as well profundal samples of this species, were also ${ }^{15} \mathrm{~N}$-depleted (mean $\delta^{15} \mathrm{~N}$ value of $+6.1 \%$ ) in comparison to other coexisting chironomids (mean $\delta^{15} \mathrm{~N}$ value of $+10.2 \%$ ) (Kolmogorov-Smirnov test, $\mathrm{p}<0.001$ ). On a dual isotopic plot (Fig. 1), the specific area of Stictochironomus sp. $\delta^{13} \mathrm{C}$ and $\delta^{15} \mathrm{~N}$ values does not overlap with that of other chironomid larvae.

The main feature of the isotopic composition of Stictochironomus sp. is a strict positive correlation between $\delta^{13} \mathrm{C}$ and $\delta^{15} \mathrm{~N}$ values $(\mathrm{r}=0.99, \mathrm{p}<0.0001)$. There was no positive correlation between carbon and

Table 1. Carbon and nitrogen stable isotope ratios for the benthic macrofaunal species, sedimentary organic carbon, and bacterial mats from profundal and littoral zones in Lake Biwa, central Japan. n: number of samples

\begin{tabular}{|c|c|c|c|c|c|c|}
\hline & \multirow{2}{*}{$\begin{array}{c}\text { Water } \\
\text { depth (m) }\end{array}$} & \multicolumn{2}{|c|}{$\delta^{13} \mathrm{C}(\%)$} & \multicolumn{2}{|c|}{$\delta^{15} \mathrm{~N}(\%)$} & \multirow[t]{2}{*}{$\mathrm{n}$} \\
\hline & & Mean & Range & Mean & Range & \\
\hline \multicolumn{7}{|l|}{ Profundal zone } \\
\hline Stictochironomus sp. & 73 & -34.3 & & 7.2 & & 1 \\
\hline Stictochironomus sp. & 40 & -64.0 & & -1.3 & & 1 \\
\hline Other Chironomidae (3 spp.) & $35-50$ & -27.7 & $(-28.6$ to -26.3$)$ & 12.2 & (11.1 to 13.1$)$ & 6 \\
\hline Oligochaeta (>5 spp.) & $35-73$ & -26.0 & $(-27.1$ to -23.9$)$ & 11.9 & (10.1 to 12.5$)$ & 22 \\
\hline Sedimentary organic carbon & $35-73$ & -25.2 & $(-25.4$ to -25.0$)$ & & & 3 \\
\hline Sulfur-oxidizing bacteria mats & $35-73$ & -30.3 & $(-31.0$ to -29.6$)$ & 3.4 & $(1.2$ to 5.8$)$ & 3 \\
\hline \multicolumn{7}{|l|}{ Littoral zone } \\
\hline Stictochironomus sp. & 20 & -30.7 & & 6.0 & & 1 \\
\hline Stictochironomus sp. & 5 & -28.9 & $(-45.4$ to -23.0$)$ & 6.1 & $(-1.0$ to 8.8$)$ & 6 \\
\hline Other Chironomidae (12 spp.) & 5 & -22.5 & $(-24.6$ to -21.2$)$ & 10.2 & (8.9 to 12.7 ) & 27 \\
\hline Sedimentary organic carbon & 5 & -22.9 & & & & 1 \\
\hline
\end{tabular}




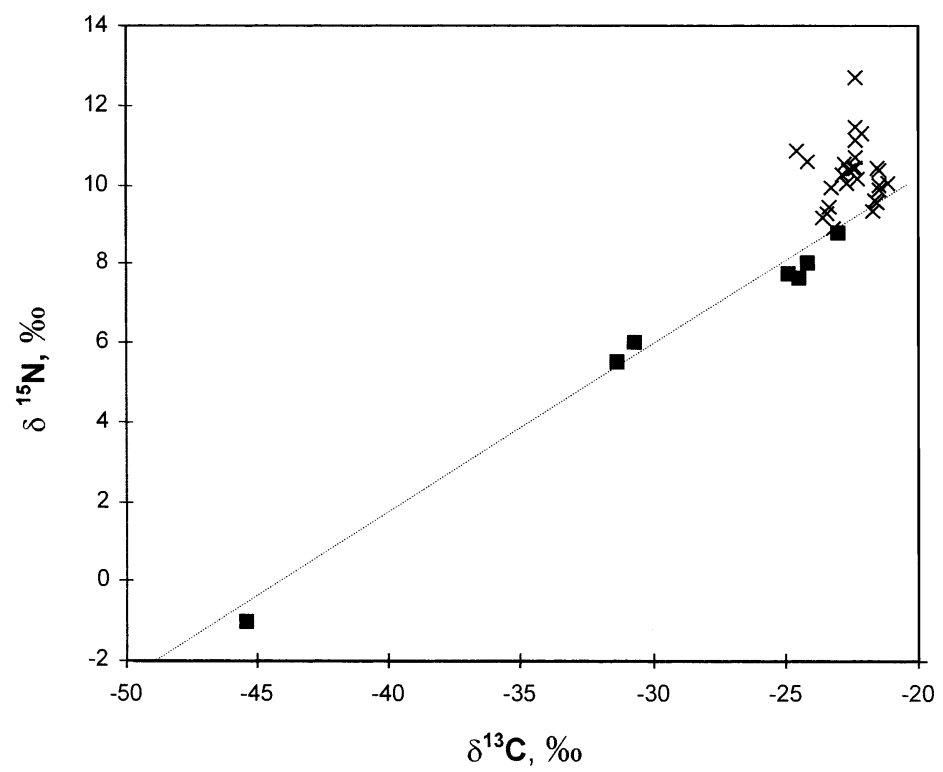

Fig. 1. Plot of $\delta^{13} \mathrm{C}$ versus $\delta^{15} \mathrm{~N}$ values (\%o) for Stictochironomus sp. larvae ( $\square$ ) and larvae of other Chironomidae species $(\times)$ inhabiting a littoral setting in Lake Biwa. A regression line, $y=18.33+0.42 x(\mathrm{r}=$ 0.99), is shown for the Stictochironomus sp. data

nitrogen isotopic ratios in the other groups of benthic animals from Lake Biwa.

Discussion. The extremely light $\delta^{13} \mathrm{C}$ values of Stictochironomus sp. in Lake Biwa are unusual for lake or marine animals. To date, $\delta^{13} \mathrm{C}$ values much lighter than $-40 \%$ have only been recorded for marine mollusks and pogonophora harboring methanotrophic bacteria as intracellular symbionts (Paull et al. 1985, Schmaljohann et al. 1990, Kennicutt et al. 1992) and there was some indication that freshwater sponge and turbellaria inhabiting a deep-water thermal seeping area in Frolikha Bay, Lake Baikal, also showed light $\delta^{13} \mathrm{C}$ values of up to $-60 \%$ o (Kuznetsov et al. 1991).

Basically, the $\delta^{13} \mathrm{C}$ and $\delta^{15} \mathrm{~N}$ values of consumers correspond to those of assimilated food with some trophic shift, an increase in ${ }^{13} \mathrm{C}$ and ${ }^{15} \mathrm{~N}$ in animal tissues: ca $+1 \%$ o for carbon and $+3.5 \%$ o for nitrogen (DeNiro \& Epstein 1978, Minagawa \& Wada 1984). The isotopic composition of main organic matter sources available to consumers of Lake Biwa has been studied (Yamada et al. 1996, 1998) and there are no primary sources in Lake Biwa that have $\delta^{13} \mathrm{C}$ values much lighter than $-31 \%$ (Fig. 2). Particulate organic matter in the Lake Biwa epilimnion showed large seasonal variations in $\delta^{13} \mathrm{C}$ values in the -30 to $-13 \%$ range, exhibiting the lowest values ( -30 to $-28 \%$ ) in winter through early spring (Yamada et al. 1998). However, the isotopic composition of sedimentary organic matter in the profundal zone of the main lake basin was rather constant, both spatially and temporally $\left(\delta^{13} \mathrm{C}\right.$ values from -25.0 to $-23.0 \%$ ) (Yamada et al. 1996, J. Murase pers. comm.). Widely distributed in Lake Biwa sulfuroxidizing chemoautotrophic bacteria Thioploca spp. (Nishino et al. 1998) were the most ${ }^{13} \mathrm{C}$ depleted primary producers. Mats of these bacteria collected in March 1999 from different sites in 35 to $70 \mathrm{~m}$ water depth range showed similar $\delta^{13} \mathrm{C}$ values of ca $-30.0 \%$ (Table 1 ). Detritus of littoral macrophytes $\left(\delta^{13} \mathrm{C}\right.$ values of -20 to $-13 \%$ ) (Yamada et al. 1998, S. Kiyashko unpubl. data) and terrigenous organic matter $\left(\delta^{13} \mathrm{C}\right.$ value ca $-27 \%$ ) (Yamada et al. 1996), which may be of importance for benthic deposit-feeders, were more ${ }^{13} \mathrm{C}$-enriched than either the plankton or sulfur bacteria.

A strong correlation between the littoral Stictochironomus sp. $\delta^{13} \mathrm{C}$ and $\delta^{15} \mathrm{~N}$ values (Fig. 1) clearly indicates a mixing of nutrition from 2 distinct sources in this species. The first source is mixed detritus derived from various photoautotrophic producers (mean $\delta^{13} \mathrm{C}$ value of ca $-23 \%$ and mean $\delta^{15} \mathrm{~N}$ value of ca $+6 \%$ o), which dominates the diet of other coexisting chironomid larvae species. The second source is unknown, but it has been characterized by $\delta^{13} \mathrm{C}$ values lighter than $-46 \%$ and $\delta^{15} \mathrm{~N}$ values lighter than $-4.5 \%$, if we suppose $\mathrm{a}+1$ and $+3.5 \%$ o trophic shift for ${ }^{13} \mathrm{C}$ and ${ }^{15} \mathrm{~N}$, respectively. We presume that methanotrophic bacteria, which oxidize biogenic methane, could provide a source extremely depleted in both ${ }^{13} \mathrm{C}$ and ${ }^{15} \mathrm{~N}$ in the lake environment. Freshwater biogenic methane has a mean $\delta^{13} \mathrm{C}$ value of $-60 \%$ (Whiticar et al. 1986, Uzaki et al. 1991) and methanotrophic bacteria are usually even more depleted in ${ }^{13} \mathrm{C}$ than the methane on which they grow (Whiticar \& Faber 1986). Methane-oxidizing bacteria can also oxidize ammonium (Hanson \& Hanson 1996), and some of them pref-

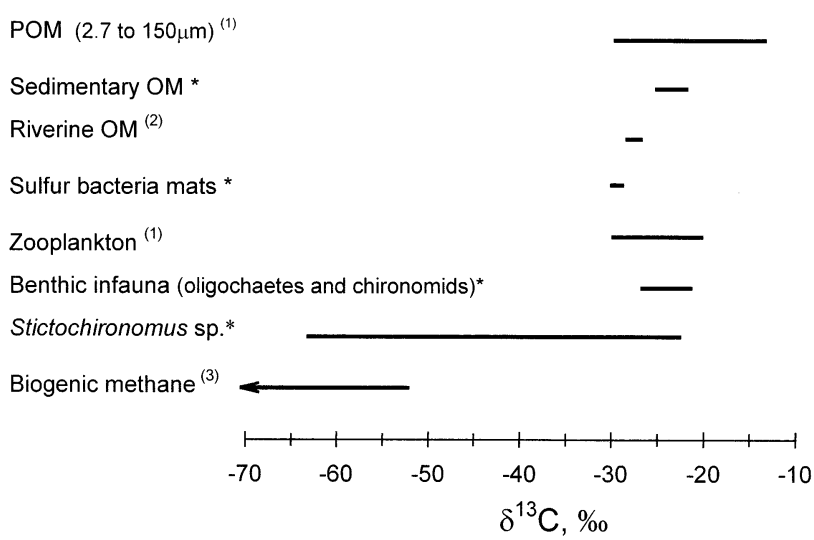

Fig. 2. Ranges of $\delta^{13} \mathrm{C}$ (\% PDB) for Stictochironomus sp. larvae, other benthic infauna, and sources of organic carbon in Lake Biwa. Asterisks indicate values reported in the present paper. Other values are from: (1) Yamada et al. (1998), (2) Yamada et al. (1996), (3) Whiticar et al. (1986), Uzaki et al. (1991) 
erentially assimilate ammonium compared to nitrate (Lee \& Childress 1994). Increased concentrations of ammonium in interstitial water can lead to essential fractionation of ${ }^{15} \mathrm{NH}_{3}$ in the course of bacterial assimilation and result in a microbial biomass highly depleted in ${ }^{15} \mathrm{~N}$ (Macko et al. 1987).

It is possible that benthic autotrophic microorganisms that assimilate ${ }^{13} \mathrm{C}$-depleted dissolved inorganic carbon, resulting from oxidation of biogenic methane or sedimentary organic matter, can be another isotopically light source for chironomid nutrition. Benthic microalgae were not sampled in this study, and there are no literature data on $\delta^{13} \mathrm{C}$ values of microalgae grown on soft bottom sediment in a freshwater environment. Other benthic autotrophic microorganisms, sulfur-oxidizing bacteria Thioploca spp., are widely distributed in the bottom sediment of Lake Biwa from the littoral to the profundal zone (Nishino et al. 1998). Thioploca samples collected from various water depths showed a very narrow range of $\delta^{13} \mathrm{C}$ values (from -31.0 to $-29.6 \%$ ) (Table 1), which are much higher than those expected for the ${ }^{13} \mathrm{C}$-depleted chironomid food source $(<-46 \%)$. Given that colorless sulfur-oxidizing bacteria discriminate against ${ }^{13} \mathrm{CO}_{2}$ to a greater degree than algae do (Ruby et al. 1987 ), we can expect that benthic microalgae would be less ${ }^{13} \mathrm{C}$-depleted than Thioploca. Moreover, substantial growth of algae is unlikely in the dark profundal zone, where the most ${ }^{13} \mathrm{C}$-depleted chironomid larvae were collected. From the above reasoning, we can conclude that autotrophic microorganisms which inhabit bottom sediment are less probable sources of extremely ${ }^{13} \mathrm{C}$-depleted organic matter for chironomids than methanotrophs are.

The stable isotopic ratios provide evidence that the chironomid larvae Stictochironomus sp., which inhabit the profundal mud and littoral sand bottom of Lake Biwa, can preferentially obtain their carbon from methanotrophic bacteria, in contrast to other species of infaunal invertebrates collected during this study. The presence of additional trophic links between chironomids and methanotrophs would lead to a substantial increase in consumer $\delta^{15} \mathrm{~N}$ values because ${ }^{15} \mathrm{~N}$ biomagnification effects ca $+3.5 \%$ in trophic transfer (Minagawa \& Wada 1984). Extremely low $\delta^{15} \mathrm{~N}$ values of some Stictochironomus samples suggest that direct feeding of chironomid larvae upon ${ }^{15} \mathrm{~N}$-depleted methanotrophs is more probable than indirect pathways, including ingestion of the protists or metazoan meiofauna eating the bacteria.

The nature of feeding association between Stictochironomus sp. larvae and methanotrophic bacteria remains obscure. Selective ingestion of the methanotrophic bacteria, the preferential harboring of microhabitats (spots or sedimentary layers) rich in methan- otrophs, or symbiosis with these bacteria, all would be assumed to be characteristic for Stictochironomus larvae. However, the very wide variation in the $\delta^{13} \mathrm{C}$ values of Stictochironomus sp. sampled from the same habitat (Fig. 1) suggests that the relationship between chironomid larvae and bacteria is less likely to be obligatory symbiosis, and suggests that the contribution of methanotrophic bacteria to the nutrition of this species can vary greatly, depending on micro-environmental conditions.

It is known that chironomid larvae can affect the distribution of methanotrophic bacteria in sediment (Kajan \& Frenzel 1999). Chironomid larvae were also found to be more ${ }^{13} \mathrm{C}$-depleted than any obvious sources in Australian billabongs (Bunn \& Boon 1993), suggesting the probable contribution of methanotrophic bacteria. Taking into account these findings and the broad distribution of Stictochironomus species in the Holarctic region (Wiederholm 1989), we suspect that the trophic association of some chironomids with methanotrophic bacteria may turn out to be a widespread phenomenon, and that chironomid larvae may be a key group of invertebrates in linking biogenic methane to the upper trophic levels of freshwater ecosystems.

Acknowledgements. We wish to thank Mr T. Koitabashi and $\mathrm{Mr} \mathrm{T}$. Ueda of the Center for Ecological Research, Kyoto University, for their help in collecting samples. We are indebted to Dr M. Yamamoto of Kankyo Kagaku, who helped T.N. to identify genera of chironomid larvae. This study was supported by Grant-in-Aid for Scientific Research on Priority Areas (A), No. 09041159, of the Ministry of Education, Science, Culture and Sports, Japan (to E.W.)

\section{LITERATURE CITED}

Bunn SE, Boon PI (1993) What sources of organic carbon drive food webs in billabongs? A study based on stable isotope analysis. Oecologia 96:85-94

Cary C, Fry B, Felbeck H, Vetter RD (1989) Multiple trophic resources for a chemoautotrophic community at a cold water brine seep at the base of the Florida Escarpment. Mar Biol 100:411-418

Cavanaugh CM (1993) Methanotroph-invertebrate symbioses in the marine environment: ultrastructural, biochemical and molecular studies. In: Murrell JC, Kelly DP (eds) Microbial growth on $\mathrm{C}_{1}$ compounds. Intercept Press Ltd, Andover, p 315-328

Childress JJ, Fischer CR, Brooks JM, Kennicutt MC II, Bidigare R, Anderson AE (1986) A methanotrophic marine molluscan (Bivalvia: Mytilidae) symbiosis: mussels fueled by gas. Science 233:1306-1308

Dando PR, Austen MC, Burke RA Jr, Kendall MA, Kennicutt MC II, Judd AG, Moore DC, O'Hara SCM, Schmaljohann R, Southward AJ (1991) Ecology of a North Sea pockmark with an active methane seep. Mar Ecol Prog Ser 70:49-63

DeNiro MJ, Epstein S (1978) Influence of diet on the distribution of carbon isotopes in animals. Geochim Cosmochim Acta 42:495-506 
Fischer C (1990) Chemoautotrophic and methanotrophic symbioses in marine invertebrates. Rev Aquat Sci 2:399-436

Hanson RS, Hanson TE (1996) Methanotrophic bacteria. Microbiol Rev $60: 439-471$

Jones RI, Grey J, Sleep D, Arvola L (1999) Stable isotope analysis of zooplankton carbon in humic lakes. Oikos 86: 97-104

Kajan R, Frenzel P (1999) The effect of chironomid larvae on production, oxidation and fluxes of methane in a flooded rice soil. FEMS Microbiol Ecol 28:121-129

Kennicutt MC II, Burke RA Jr, MacDonald IR, Brooks JM, Denoux GJ, Macko SA (1992) Stable isotope partitioning in seep and vent organisms: chemical and ecological significance. Chem Geol (Isot Geosci Sect) 101:293-310

Kuznetsov AP, Strizhov VP, Kuzin VS, Fialkov VA, Yastrebov VS (1991) The novelty in Baikal nature - a community based on bacterial chemosynthesis. Izv Akad Nauk SSSR Ser Biol 5:766-772

Lee RW, Childress JJ (1994) Assimilation of inorganic nitrogen by marine invertebrates and their chemoautotrophic and methanotrophic symbionts. Appl Environ Microbiol 60:1852-1858

Macko SA, Fogel ML, Hare PE, Hoering TC (1987) Isotopic fractionation of nitrogen and carbon in the synthesis of amino acids by microorganisms. Chem Geol (Isot Geosci Sect) 65:79-92

Minagawa M, Wada E (1984) Stepwise enrichment of ${ }^{15} \mathrm{~N}$ along food chains: further evidence and the relation between $\delta^{15} \mathrm{~N}$ and animal age. Geochim Cosmochim Acta 48:1135-1140

Mori S (1978) Seventh report of the regular limnological survey of Lake Biwa. III Benthos. Mem Coll Sci Kyoto Univ Ser B (Biol) 7(2):11-29

Nishino M, Fukui M, Nakajima T (1998) Dense mats of Thioploca, gliding filamentous sulfur-oxidizing bacteria in Lake Biwa, central Japan. Water Res 32:953-957

Okamoto I, Morikawa M (1961) Water circulation in Lake

Editorial responsibility: John Dolan,

Edgewater, Maryland, USA
Biwako as deduced from the distribution of water density. Jpn J Limnol 22:193-200

Okuda S, Kumagai M (1995) Introduction. In: Okuda S, Imberger J, Kumagai M (eds) Physical processes in a large lake: Lake Biwa, Japan. Coastal and estuarine studies, Vol 48. American Geophysical Union, Washington, DC, p $1-13$

Paull CK, Jull AJT, Toolin LJ, Linick T (1985) Stable isotope evidence for chemosynthesis in an abyssal seep community. Nature 317:709-711

Ruby EG, Jannasch HW, Deuser WG (1987) Fractionation of stable carbon isotopes during chemoautotrophic growth of sulfur-oxidizing bacteria. Appl Environ Microbiol 53: 1940-1943

Schmaljohann R, Faber E, Whiticar MJ, Dando PR (1990) Coexistence of methane- and sulphur-based endosymbioses between bacteria and invertebrates at a site in the Skagerrak. Mar Ecol Prog Ser 61:119-124

Uzaki M, Mizutani H, Wada E (1991) Carbon isotope composition of $\mathrm{CH}_{4}$ from rice paddies in Japan. Biogeochemistry 13:159-175

Whiticar MJ, Faber E (1986) Methane oxidation in sediment and water column environments - isotope evidence. Org Geochem 10:759-768

Whiticar MJ, Faber E, Schoell M (1986) Biogenic methane formation in marine and freshwater environments: $\mathrm{CO}_{2}$ reduction vs. acetate formation - isotope evidence. Geochim Cosmochim Acta 50:693-709

Wiederholm T (ed) (1989) Chironomidae of the Holarctic region. Key and diagnoses. Part 3. Adult males. Entomol Scand Suppl 34:1-532

Yamada Y, Ueda T, Wada E (1996) Biogeochemical framework of the Yodo River watershed from stable isotopic viewpoints. Jpn J Limnol 57:467-477

Yamada Y, Ueda T, Koitabashi T, Wada E (1998) Horizontal and vertical isotopic model of Lake Biwa ecosystem. Jpn J Limnol 59:409-427

Submitted: November 6, 2000; Accepted: March 1, 2001

Proofs received from author(s): April 11, 2001 